\title{
Treatment of Indianness and Indian Lexical Items in the Poetry of Jayanta Mahapatra
}

\author{
Hemanta Rajbanshi*, Dr. Bairagi Patra \\ Research scholar, Department of Language and Literature, Utkal University of Culture Bhubaneswar \\ *Corresponding Author: Hemanta Rajbanshi, Research scholar, Department of Language and \\ Literature, Utkal University of Culture Bhubaneswar
}

\begin{abstract}
Treatment of Indianness is a common and much discussed topic in the field of Indian literary discussion and criticism. There are many Indian poets, who are well acclaimed for their treatment of Indianness in their poetry. Jayanta Mahapatra is also one among them who has occupied a special place for his depiction of Indian art, culture, history and social reality in his poetry. His treatment of Indian lexical items is extraordinary, in the sense that they are chosen from his experience, they are chosen from the real India, and they are chosen from the traditions and cultures where he was grown up. Mahapatra's lexical items include both local and Indian vocabularies, his conscious translations which are unique with Indian flavour, shifts, borrowing lexical items, hybridized formations etc.
\end{abstract}

Keywords: Indianness, lexical, shifts, hybridized, culture, reality

\section{INTRODUCTION}

In this study, we try to focus the issue of Indianness and the Indian lexical items used by Jayanta Mahapatra from a socio-cultural and linguistic point of view. The issue of Indianness reflected in the works of Indian English literature is a much discussed and debated topic among the high brow people. It is often seen that the Indian writers, whether poets or novelists or any prose writers, are conscious enough about their Indian identity. According to Meenakshi Mukharjee, this tendency is nothing but an 'anxiety of Indianness'. For Gokak, "It is easy to slip into thinking that Indianness consists in adopting an angle of vision which is recognizably vedantic" (Gokak in Mohan, 1978, p.23). Besides this vedantic view, however, as he argues, there are other world views too presented by Indian literature. These are- Marxist, socialist, existentialists etc. According to Gokak, mysticism is an important feature found in the Indian literature which is a very common theme found in other literatures too. He says, "An expression of occult experience is not the monopoly of Indo-Anglican or Indian writers. Blake and the romantics and the poets of the Irish revival like A.E. Houseman and W. B. Yeats are full of it.This too, is a feature which distinguishes the work of all great writers in world literature"(Gokak in Mohan, 1978,pp.23-24).

\section{DEFINITIONS OF INDIANNESS}

It is difficult to find out the definition of Indianness in an individual writer by considering the geography, race, religion, language etc. The main point to be considered is the awareness towards the Indian culture, the glorious history of India. To quote Gokak again, "Indianness of Indian writing consists in the writer's intense awareness of his entire culture" (Gokak in Mohan, 1978, p. 24). The great Indian history, its five thousand years old glorious culture from Kashmir to Cape Camorin, the nature and the people, all these should have a place in the writings of the writers. All these should be a part of the consciousness of the writers.

Regarding the definition of Indianness, Naik says that Indian poetry in English carries the identity as 'Indian' but they are sometimes 'Indian' and occasionally 'poetry'. The genuineness of a good number of poetry is also not beyond doubt. In this regard, Gokak remarks, "Publication in the field of Indo-Anglican poetry has been ample and indiscriminate. For every recognisable book of IndoAnglican poems I have read I have probably read ten that need not have been read at all" (Gokak in Mohan, 1978, p.xii) 
Archana Kumar, in his 'The Poetry of Jayanta Mahapatra' says about this issue, "If an Indian poet chooses an Indian theme or makes use of an Indian setting, it in itself will not result in good writing. If the poet uses a local colour purely as an external device, it is not enough. He is not influenced merely by one culture. Rather, he carries the burden of diversity of cultural strands; Indianness in his works may also take several forms" (Kumar, 2006, p.144). The words of Naik, in this regard is also worth mentioning, "Among the most prominent elements in this synthesis are a quest for the eternal verities, a passion for assimilation and acceptance and an agility and elasticity of mind which is capable of at once rigorous intellectual scrutiny and unquestioning faith as the mood dictates" (Naik, 1983, p. 33).

It has already been stated that defining Indianness is not a simple task. Whether in terms of sociocultural issue or in art and literature, we cannot define it easily. Because, for different people, these elements of history, art and culture bear different meanings. For example, an orientalist or a nationalist or a communalist views Indian history from different perspectives. Some of them may be attracted towards the non-modern or ancient Indian spirituality of Indian heritage, while some others may be attracted towards the Hindu tradition of India.

However, it should also be kept in mind that Indianness is not something which can be practiced by the Hindu poets or writers only. There are lots of prominent non-Hindu authors and poets who have equally demonstrated the glory of Indian history, culture and heritage through their writings.

Regarding the problems of an Indian English writer, Raja Rao says, "The telling has not been easy. One has to convey various shades and omissions of a certain thought-movement that looks maltreated in an alien language. I use the word 'alien', yet English is not really an alien language to us. It is the language of our intellectual make up like Sanskrit or Persian was before-but not of our emotional make up. We are instinctively bilingual, many of us writing in our own language and in English. We should not. We can write only as Indians. We have grown to look at the large world as part of us. Our method of expression has to be a dialect which will someday prove to be as distinctive and colourful as the Irish or the American. Time alone will justify" (quoted in Kachru, 1983, p.44).

To speak about language, Indianness of English may be unearthed at various levels of linguistic study-phonology, lexis, syntax and semantics.

\section{INDIANNESS AND JAYANTA MAHAPATRA}

Jayanta Mahapatra, whether from socio-cultural perspective or from the use of Indian lexical items, is truly an 'Indian' poet. As Archana Kumar views, "Mahapatra writes in English because he knows little Oriya, but he prefers to call himself an 'Oriya poet' who incidentally writes in English and wishes that his poems may be read as 'translation'. He accepts that it took him a long time to use English effectively in his writing. He makes no tall claims for writing in English or for Indian English poetry. He is rather hesitant about the achievement of Indian English poetry" ('The Poetry of Jayanta Mahapatra', pp.152-153).

The poet Jayanta Mahapatra has great social responsibility on his shoulder and it is reflected in his views. He says, "Most English poetry in this country fails because our poets are simply unaware of the society from which the poetry emerges, because being 'city poets', they deal with the basically uninspiring middle class and their poetry turns out to be equally uninspiring. They produce a kind of 'willed' poetry that is forced out of their 'selves' and which ignores the rural psyche, for only when this human condition is embodied in the right language, the poetry tends toward the epic or classic nature..the poetry remains fundamentally a thick undergrowth but unable to satisfy the demands of the earth which bears it" (Mahapatra, 1980, p. 34).

If we see the socio-political condition in post-independence India, we find the treatment of essentially Indian topics in the poetry of Jayanta Mahapatra. These are- hunger, communalism, casteism, superstition and ignorance of the political leaders of the suffering of the people of the country. Regarding the depiction of social reality in the poetry of Jayanta Mahapatra, Paniker says, "A fact worth noting about the more recent poems of Jayanta Mahapatra is that they appear to reveal an increasing concern on the part of the poet with contemporary reality with all its political connotations, from preoccupation with timeless myth, he has extended his range of interest to include reality, still glimmering in the light of reason not yet metamorphosed into myth" (Paniker, in Shahne and Shivramkrishna, 1980, p. 113). 
Social reality is one of the core themes of Mahapatra. In one of his poems, Mahapatra reminds us about the evil system of 'sati' through the modern instances of women burning for dowry-

"...The house

On the main street looks insignificant although

Its mouth is slack with the piteous screams

Of the girl burnt to death last August

In the room on the landing. An old woman

Can not fall asleep denying emotion about it,

..it does not bother

The sun or the government." ("In the Autumn Valley of the Mahanadi")

The extreme mental and physical pain experienced by a rape victim is very realistically presented in the poem, 'Learning for Ourselves' and 'The Lost Children of America'.

"Last year on the bend of the Debi River

The rape of a young girl

Shocked us like ripe mangoes

Dropping from the bare trees in winter.

Last year her murder and dismemberment

Made us understand somewhat

The trembling in the eyes of cows we see

Being led meekly to the town's slaughter-house."

("Learning for Ourselves") Again,

"In the Hanuman Temple last Night

The priest's pomaded jean clad son

Raped the squint eyed fourteen year old fisher girl

On the naked stone platform behind the shrine

And this morning

Her father found her at the police station

Assaulted over and over again by four policeman

Dripping of darkness and of scarlet death." (The Lost Children of America")

Mahapatra along with others experienced the pre-Independence dreams and sufferings, sacrifices and agonies of the countrymen and left a disillusioned person with shattered hopes. He records his experiences in poems like, 'Heroism', 'The Twenty-fifth Anniversary of Republic:1975', '30 January 1982: A story’, ‘A Missing Person', etc.

a) "As in film, this talk of freedom

Freedom from want, social justice

Poised over the bleeding heartland."

b) "The Photograph of Gandhi in the new airport Lounge

Is more than forty years old.

Every time I look into the old man's eyes

He calmly hands back my promise back to me."

c) "A parliament groans under

The weight of another debate."

Mahapatra presents the bitter reality of the society in such a way-

"This is a barren land that has been 
Prowling round my room,

Epidemics in the poisoned air

Dusty streets stretching away like disgruntled socialists" (“A Fahter's Hours”)

Again he says-

"And in the earth-sounds

Of bare feet slapping the village road,

The famine's air and drought,

A reality which would offend the gods;

The aroma of ripe fruit squashed on rock" ("Dusk")

Regarding Mahapatra's treatment of the reality of Indian life, Archana Kumar says, "To present the reality of Indian life, Mahapatra uses native words, 'translates; number of Indian expressions, idioms etc., and imposes the syntax of Indian language although without much violence to English grammar. In this process of imparting 'Indian' flavour to his verse, he also uses technique of literal translation; he usually uses conscious translations to 'Indianise' the situation." ("The Poetry of Jayanta Mahapatra" p.168). He suggests the following examples-

i. A six-month-old child

Crawls across the dung-washed floor

ii. ...death ashes

Half-burnt logs and tombs

Of urn make no sense

iii. Town's burning ground

iv. The starlight at the window stares

At the perfumed innocence of her painted hands

v. Languor softly grips her belled feet

vi. Cross legged sunk in his rope-cot through the day

He pores devoutly over papers across wriggly letters

That wear the fate of planets, stars.

vii. A sacred thread the colour of his hidden bone

The tangle of hard births in the unshaven lock

Of holy hair behind the head.

viii. Balls of cooked rice to appease the dead

ix. Chariot-festival at Puri.

Shifts are also present abundantly in the poetry of Jayanta Mahapatra. A shift is not a translation. Unlike a translation, here, no attempt is made to establish formal equivalence. 'An Indianism clsssified as shift is usually an adaptation of an underlying formal item of an Indian language'. In the poetry of Mahapatra, a large number of Indianisms are observed which can better be treated as shifts. Few of such examples are mentioned below-

i. The sullen old temple

Where a newly-married couple stands

Palms stretched towards the priest.

ii. There is light talk of rioting and murder

On the festive day of Durga's immersion. 
iii. Now a near naked man ends his bath

Exorcised by generations

Between his folded palms, a ghost of morning sun

iv. Why is my skin so brown, why my birth not final?

Why do I seek a virgin woman for my wife?

Why do I grovel before that grotesque god of bitter wood?

v. The slow cold ache

Of parading themselves before their prospective grooms

Besides these, borrowing also plays a very important role in enriching Indian lexis. There are also lexical inventions in Indian English. The following are such examples found in the poetry of Jayanta Mahapatra-

i. Faint stars drift on with their mantras of survival.

ii. a colourless monsoon

Eaten away by what has drifted between

iii. bleeding dubas

iv. Alasi

v. Her breath warm as the loo that blows in summer

vi. The slow dawn mists linger

in the forgotten old pipals by the river

$v i i$. His flowing white beard-the kurukshetra

On the flag before dawn

viii. His jaws move to mantras

ix. these masters of surprise

of ghareo, of master plot

$\mathrm{x}$. The unseen hands of gods

in front of a garish temple of the simian Hanuman.

A hybridized formation is also seen in the borrowed words of Mahapatra. A hybrid word is a lexical formation where there are two or more elements out of which at least one is from an Indian language and one from English. The following are a few examples of such hybridized lexis found in Jayanta Mahapatra-

i. Hands that keep their hold

on coins in their pockets

with peaceful Gandhi heads.

ii. Swifts, like spirits

claim the lost

air of shakuni-skies

iii. the fearsome Brahmin priest

In alleviative belief

Using darkness to be a protent of the gods

iv. But the air still gives off her dead grandmother's pan-stained breath 
v. Through the spread of alasi flowers.

Indian collocations are another feature of Indianness found in the poetry of Jayanta Mahapatra. Archana Kumar observes three types of such collocations in Mahapatra's poetry. These are, a) loan shifts from Indian language b) collocation ally Indian words and c) contextual units assigned in Indian culture which are absent in British culture.

\section{CONCLUSION}

So, in conclusion, we can say that with the characteristics of all these features discussed above, Mahapatra's poetry is purely Indian. The Indian lexis used by him has reached a special position in his hands. The Indian culture, history, and its people are beautifully and realistically presented through such lexical items.

\section{REFERENCES}

Primary Sources

[1] Mahapatra, Jayanta. Close the Sky, Ten by Ten, Calcutta: Dialogue Publications, 1971.

A Father's Hours. Calcutta: United Writers.1976.

Relationship. New York: The Greenfield Review Press, 1980.

The Inaudible Resonance in English Poetry in India”. Literary Criterion 15.1 (1980):pp.27-36.

Secondary Sources

[1] Mukharjee, Meenakshi, Considerations. New Delhi: Allied Publishers, 1977.

[2] Mohan, Ramesh, ed. Indian Writing in English. New Delhi: Orient Longman, 1978.

[3] Naik, M.K. A History of Indian English Literature. New Delhi: Sahitya Akademi, 1982.

[4] Kumar, Archana, the Poetry of Jayanta Mahapatra. New Delhi: Arya Publishing House, 2006.

[5] Kachru, Braj B. The Indianisation of English. New Delhi: Oxford University Press, 1983.

[6] Shahane, V.A. and M. Shivramkrishna, eds. Indian Poetry in English: A Critical Assessment. New Delhi: Macmillan, 1980.

\section{AUTHORS' AUTOBIOGRAPHY}

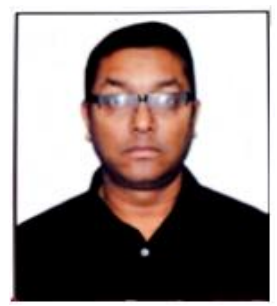

Hemanta Rajbanshi, is a Research Scholar at Utkal University of Culture, Bhubaneswar, Odisha in the department of Language and Literature. His academic qualification is MA (English Literature), B.Ed. and Mphil. He has more than fifteen years of teaching experiences in different colleges and Higher Secondary schools. Till date, he has published more than 7 research papers in different National and International journals. He has also authored more than three books. His book, "Language and Curriculum Transaction" written for the students of B.Ed under Gauhati University, Assam has been well received by the student and teaching community.

Rajbanshi is also a freelance writer, contributing various short stories, articles and poems in different regional English and Assamese news papers, journals and periodicals.

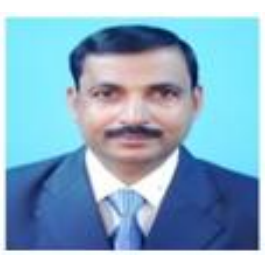

Dr.Bairagi Patra, MA(English Linguistics)M.Phil. PhD-English-Linguistics ,TESOL with 15 Yrs Experience faculty of English-Linguistics, Dept.of Linguistics, Utkal University of Culture, Odisha. He is currently guiding six $\mathrm{PhD}$ research scholars. Areas of Specialization-Linguistics, English Language, ELT CLT, Communicative Grammar, He’s the Head-ELT@I: Bhubaneswar Chapter, Odisha who organised five National Seminar -workshop, chairing session \&presented papers in International Conference by British Council, ELT@I with foreign tour to Bangkok, Thailand for this. He has 15 Internal \& National Journal publications

Citation: Hemanta Rajbanshi \& .Dr.Bairagi Patra. Treatment of Indianness and Indian Lexical Items in the Poetry of Jayanta Mahapatra. "International Journal on Studies in English Language and Literature (IJSELL), vol 8, no. 1, 2020, pp. 28-33. doi: http://dx.doi.org/10.20431/2347-3134.0801004.

Copyright: (C) 2020 Authors. This is an open-access article distributed under the terms of the Creative Commons Attribution License, which permits unrestricted use, distribution, and reproduction in any medium, provided the original author and source are credited. 